\title{
Optimum $\mathrm{O}_{2}$ or $\mathrm{CO}_{2}$ Atmosphere for Storing Broccoli Florets at Various Temperatures
}

\author{
Hidemi Izumi ${ }^{1}$, Alley E. Watada ${ }^{2}$, and Willard Douglas \\ Belts vine Agricultural Research Center, Agricultural Research Service, U.S. Department of Agriculture, \\ Beltsville, MD 20705
}

Additional index words. Brassica oleracea, controlled atmosphere, respiration, ethylene production, hue angle, deterioration, off-odor

\begin{abstract}
Marathon' broccoli (Brassica oleracea $\mathrm{L}$. var. italica) florets were stored in air, low $\mathrm{O}_{2}(0.25 \%, 0.5 \%$, and $1 \%)$ or high $\mathrm{CO}_{2}(3 \%, 6 \%$, and $10 \%)$ at 0,5 , and $10 \mathrm{C}$. Oxygen consumption and $\mathrm{CO}_{2}$ production were reduced under low $\mathrm{O}_{2}$ or high $\mathrm{CO}_{2}$ atmosphere, the reduction being greater at lower $\mathrm{O}_{2}$ and higher $\mathrm{CO}_{2}$ levels. Nodifferences were found in ethylene production among the different atmospheres. Low $\mathrm{O}_{2}$ and high $\mathrm{CO}_{2}$ retained color of broccoli florets to about the same extent at $10 \mathrm{C}$ but had no effect at 0 and $5 \mathrm{C}$. Development of soft rot and browning was suppressed by low $\mathrm{O}_{2}$ or high $\mathrm{CO}_{2}$, but offensive off-odor occurred in $0.25 \% 02$ at all temperatures and $0.5 \% \mathrm{O}_{2}$ at $10 \mathrm{C}$. These results indicate that the best $\mathrm{O}_{2}$ and $\mathrm{CO}_{2}$ levels seem to be $0.5 \% \mathrm{O}_{2}$ and $10 \% \mathrm{CO}_{2}$ at $\mathrm{O}$ and $5 \mathrm{C}$, and $1 \% \mathrm{O}_{2}$ and $10 \% \mathrm{CO}_{2}$ at $10 \mathrm{C}$.
\end{abstract}

A controlled atmosphere with reduced $\mathrm{O}_{2}$ and/or elevated $\mathrm{CO}_{2}$ reduces respiration (Kasmire et al., 1974; Lebermann et al., 1968), ethylene production (Wang, 1979), weight loss (Anelli et al., 1984; Makhlouf et al., 1989a), and decay (Lipton and Harris, 1974; Makhlouf et al., 1989a) and retards yellowing (Kasmire et al., 1974; Lebermann et al., 1968; Lipton and Harris, 1974; Wang, 1979; Makblouf et al., 1989a) of broccoli heads. Based on these results, lowering $\mathrm{O}_{2}$ to $1 \%$ to $2 \%$ and/or increasing $\mathrm{CO}_{2}$ to $5 \%$ to $10 \%$ is recommended for storing broccoli heads to maintain quality at 0 to 5C (Saltveit, 1993). With the increasing demand for lightly processed vegetables, controlled or modified atmosphere for broccoli florets also has been researched over the past few years (Ballantine et al., 1988; Barth et al., 1993; Bastrash et al., 1993; Berrang et al., 1990). However, these studies were conducted only at a single temperature, which differed among the studies.

Since the optimum storage atmosphere can differ with storage organ-commodity and storage temperature, our objective was to determine the optimum treatment atmosphere for storage of broccoli florets at 0,5 , and $10 \mathrm{C}$. The $10 \mathrm{C}$ was included because the temperature of a few commercial holding rooms approaches 10C. Optimum atmosphere was based on physiological activity and visual quality of the florets. Oxygen levels below $1 \%$ were examined in this study because the internal $\mathrm{O}_{2}$ content in broccoli heads probably drops substantially below $1 \%$ when using $1 \%$ to $2 \% \mathrm{O}_{2}$ atmosphere. In broccoli heads, compared to the florets, the gas diffusion is more limited, which causes a larger gradient in gas concentration from the external to internal tissue (Brecht, 1980).

\section{Materials and Methods}

Heads of 'Marathon' broccoli were obtained from the Wholesale distribution center in Jessup, Md., and separated with a knife into florets of about $15 \mathrm{~g}$ each. A 150-g sample was placed on an elevated screen in a 2-liter glass jar with $100 \mathrm{ml}$ of distilled water in the bottom to maintain high relative humidity. Three replicated samples were stored at $\mathrm{O}, 5$, and $10 \mathrm{C}$ under a continuous stream of

Received for publication 8 Dec. 1995. Accepted for publication 9 May 1995. Use of a company or product name by the U.S. Dept. of Agriculture. does not imply approval or recommendation of the product to the exclusion of others which also may be suitable. The cost of publishing this paper was defrayed in part by the payment of page charges. Under postal regulations, this paper therefore must be hereby marked advertisement solely to indicate this fact.

'Present address: Kinki Univ., Naga, Wakayama, 649-64 Japan.

${ }^{2}$ Research leader, Horticultural Crops Quality Laboratory. To whom reprint requests should be addressed.

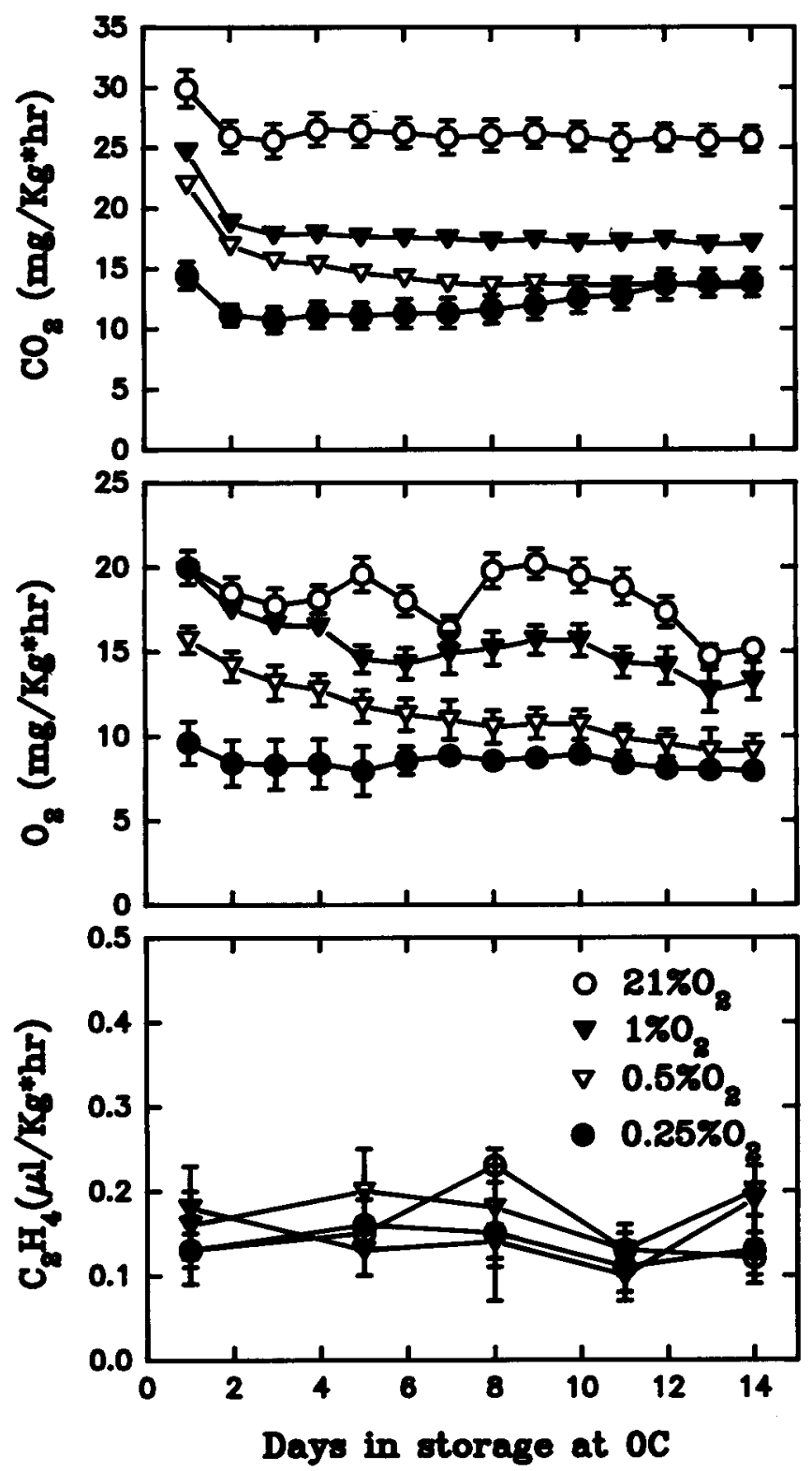

Fig. 1. Rates of $\mathrm{CO}_{2}$ production, $\mathrm{O}_{2}$ consumption, and ethylene production of broccoli florets during storage at $0 \mathrm{C}$ under air or low $\mathrm{O}_{2}$ atmospheres. Vertical lines represent SE. SE bars not shown when within symbols. 

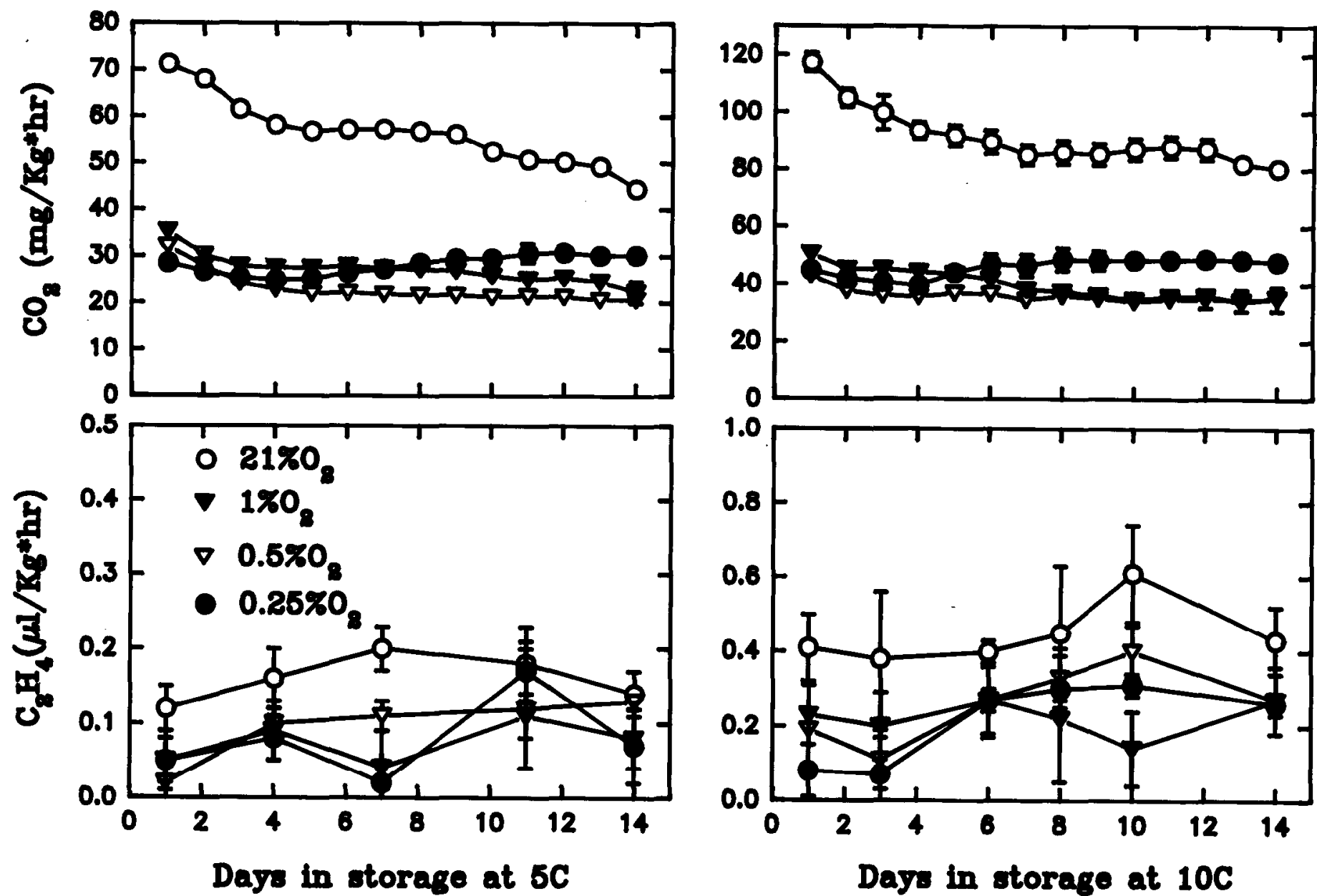

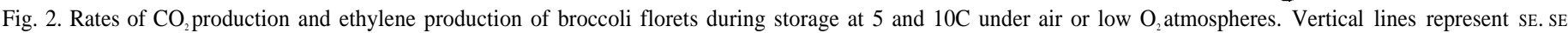
bars not shown when within symbols

air, low $\mathrm{O}_{2}(0.25 \%, 0.5 \%$, and $1 \%)$ or high $\mathrm{CO}_{2}(3 \%, 6 \%$, and $10 \%)$ atmosphere at 10,20 , and $40 \mathrm{ml} \cdot \mathrm{min}^{-1}$, respectively. The balance of the mixture was $\mathrm{N}_{2}$ for the low $\mathrm{O}_{2}$ atmosphere, and $\mathrm{N}_{2}$ and air to give a minimum of $19 \% \mathrm{O}_{2}$ for the high $\mathrm{CO}_{2}$ atmosphere. Different lots of broccoli were used for the low $\mathrm{O}_{2}$ and the high $\mathrm{CO}_{2}$ studies.

Oxygen and $\mathrm{CO}_{2}$ contents of inlet and outlet streams of each jar were monitored with an oxygen analyzer and carbon dioxide analyzer (model S-3A/I and model CD-3A; Ametek, Pittsburgh). Ethylene levels in 5-ml gas samples taken from each jar were measured with an analytical gas chromatography (Model AGC211; Carle, Tulsa, Okla.), equipped with a flame ionization detector. Color, decay, and odor were evaluated after storage. The color [hue angle, $\left.\tan ^{-1}\left(\mathrm{~b}^{*} / \mathrm{a}^{*}\right)\right]$ of the central part of the inflorescence was determined using a chroma meter (model CR-300; Minolta, Japan), with a $1-\mathrm{cm}$ aperture. Incidence of soft rot and browning were expressed as a percentage of the total number of florets inspected. Raw and cooked odor of florets that had been placed in a microwave oven for 2 min were rated on a scale of 0 to 4 , with $0=$ normal and $4=$ severely objectionable.

\section{Results}

Carbon dioxide production and $\mathrm{O}_{2}$ consumption of florets held at $0 \mathrm{C}$ were lower with decreasing $\mathrm{O}_{2}$ revels (Fig. 1). However, $\mathrm{CO}_{2}$ production of florets at $0.25 \% \mathrm{O}_{2}$ decreased on day 2 , and then increased gradually thereafter and approached the rate of those held at $0.5 \% \mathrm{O}_{2}$ by day 10 , with samples held at $0 \mathrm{C}$. In comparison, the $\mathrm{CO}_{2}$ production rates of samples in $0.25 \%$ and $1 \% \mathrm{O}_{2}$ merged on day 7 at $5 \mathrm{C}$ and day 5 at 10C (Fig. 2). Carbon dioxide production of samples held in $0.25 \% \mathrm{O}_{2}$ was higher than those held in $0.5 \%$, and $1 \% \mathrm{O}_{2}$ after day 11 at $5 \mathrm{C}$, and day 8 at $10 \mathrm{C}$ (Fig. 2). No major differences were found in ethylene production between samples in air and low $\mathrm{O}_{2}$ atmospheres at all temperatures (Figs. 1 and 2).

Green color, expressed as hue angle, was retained in florets stored in all atmospheres at 0 and $5 \mathrm{C}(127.1 \pm 1.1)$, whereas it decreased by $80 \%$ from the initial value for florets in air at $10 \mathrm{C}$ $(104.7 \pm 1.6)$. Low $\mathrm{O}_{2}$ levels suppressed the development of soft rot on flower buds and browning of cut surfaces at 0C (Table 1). Browning was only suppressed at 5 and 10C. Soft rot incidence was not affected at 5C, but increased when florets were held in $0.25 \%$ and $0.5 \% \mathrm{O}_{2}$ atmospheres at 10C. An offensive off-odor was produced by raw florets held in low $\mathrm{O}_{2}$ at all temperatures except $1 \% \quad \mathrm{O}_{2}$ at $0 \mathrm{C}$. After cooking, however, the odor was not detected with samples held at 0 and $5 \mathrm{C}$ in $0.5 \%$ and $1 \% \mathrm{O}_{2}$ and was minimal with samples at $10 \mathrm{C}$ in $1 \% \mathrm{O}_{2}$.

High $\mathrm{CO}_{2}$ atmosphere inhibited $\mathrm{CO}_{2}$ production of florets held at $0 \mathrm{C}$, with the inhibition being greater in $10 \%$ or $6 \% \mathrm{CO}_{2}$ (Fig. 3 ). This pattern of differences among treatments was also observed at 5 and 10C (Fig. 4). Oxygen consumption tended to be lower in high $\mathrm{CO}$, atmosphere than in air at $0 \mathrm{C}$, although the difference was not as defined as that in $\mathrm{CO}_{2}$ production (Fig. 3). There were no significant differences in ethylene production between air and high $\mathrm{CO}$, atmospheres at all temperatures, except for the initial day at 0C (Figs. 3 and 4).

High $\mathrm{CO}_{2}$ had no effect on retention of green color at 0 and $5 \mathrm{C}$, but did retard its loss at $10 \mathrm{C}$, as noted with low $\mathrm{O}_{2}$ atmosphere (data 
Table 1. Incidence of soft rot and browning and development of objectionable odor during storage of broccoli florets at 0,5 , and $10 \mathrm{C}$ under air or low $\mathrm{O}_{2}$ atmospheres.

Storage

$\begin{array}{lcc}\left({ }^{\circ} \mathrm{C}\right) & \text { Treatment } & \text { Soft } \text { rot }^{2} \\ 0 & 21 \% \mathrm{O}_{2} & 20 \mathrm{a}^{\mathrm{x}} \\ & 1 \% \mathrm{O}_{2} & 4 \mathrm{~b} \\ & 0.5 \% \mathrm{O}_{2} & 0 \mathrm{~b} \\ & 0.25 \% \mathrm{O}_{2} & 0 \mathrm{~b} \\ 5 & 21 \% \mathrm{O}_{2} & 17 \mathrm{a} \\ & 1 \% \mathrm{O}_{2} & 21 \mathrm{a} \\ & 0.5 \% \mathrm{O}_{2} & 21 \mathrm{a} \\ & 0.25 \% \mathrm{O}_{2} & 11 \mathrm{a} \\ 10 & 21 \% \mathrm{O}_{2} & 37 \mathrm{~b} \\ & 1 \% \mathrm{O}_{2} & 45 \mathrm{ab} \\ & 0.5 \% \mathrm{O}_{2} & 59 \mathrm{a} \\ & 0.25 \% \mathrm{O}_{2} & 61 \mathrm{a}\end{array}$

\begin{tabular}{ll}
\multicolumn{2}{c}{ Odor $^{y}$} \\
Raw & Cooked \\
$0 \mathrm{c}$ & $0 \mathrm{~b}$ \\
$0 \mathrm{c}$ & $0 \mathrm{~b}$ \\
$1.5 \mathrm{~b}$ & $0 \mathrm{~b}$ \\
$2.0 \mathrm{a}$ & $3.0 \mathrm{a}$ \\
$1.0 \mathrm{~d}$ & $0 \mathrm{~b}$ \\
$1.7 \mathrm{C}$ & $0.7 \mathrm{~b}$ \\
$2.0 \mathrm{~b}$ & $0.7 \mathrm{~b}$ \\
$3.0 \mathrm{a}$ & $3.0 \mathrm{a}$ \\
$1.0 \mathrm{c}$ & $0 \mathrm{~d}$ \\
$1.0 \mathrm{c}$ & $1.0 \mathrm{c}$ \\
$2.3 \mathrm{~b}$ & $2.0 \mathrm{~b}$ \\
$3.0 \mathrm{a}$ & $3.0 \mathrm{a}$
\end{tabular}

'(Number of injured florets/ 100 number of observed florets) $\times 100$.

${ }^{y}$ Rated on a scale of 0 to 4 , with $0=$ normal and $4=$ severely objectionable. ${ }^{\times}$Mean separation within each temperature by Duncan's multiple range test, $P=0.05$.

not shown). Soft rot, browning, and off-odor were minimal in high $\mathrm{CO}_{2}$ atmosphere at all temperatures, while the incidence of soft rot in air at $10 \mathrm{C}$ was about five times greater than that in high $\mathrm{CO}_{2}$ at 10C (Table 2). No off-odor occurred after cooking samples held in high $\mathrm{CO}_{2}$ atmospheres at all temperatures.

\section{Discussion}

Respiration rate of broccoli florets was reduced by both low $\mathrm{O}_{2}$ and elevated $\mathrm{CO}_{2}$. The effect was greater at 5 and $10 \mathrm{C}$ when florets were held in $\mathrm{O}_{2}$ levels of $1 \%$ or less compared to $\mathrm{CO}_{2}$ levels of up to $10 \%$. Lebermann (1968) reported that respiration of broccoli heads was reduced when held in $2 \% \mathrm{O}_{2}$ or $20 \% \mathrm{CO}_{2}$ at $7 \mathrm{C}$, but the reduction was similar in both atmospheres. With florets in our study, the greater effect of $\mathrm{O}_{2}$ relative to $\mathrm{CO}_{2}$ may have been due to a change in the mechanism by which low $\mathrm{O}_{2}$ reduced the respiration rate, because respiratory quotient (RQ) was higher in florets held in $0.25 \% \mathrm{O}_{2}$ than in air, but lower in those held in high $\mathrm{CO}_{2}$ atmospheres (data not shown). As the $\mathrm{O}_{2}$ level was reduced to $0.25 \%$, respiration may have changed from the aerobic to anaerobic pathway, and this shift would occur more readily at 5 and $10 \mathrm{C}$ than at $0 \mathrm{C}$. High $\mathrm{CO}_{2}$ has been shown to reduce respiration rate, the mechanism of action is unknown, but may be associated with changes in the Krebs cycle (Kader, 1986).

Ethylene production was minimal and green color was retained with florets held in low $\mathrm{O}_{2}$ at $10 \mathrm{C}$. Others have reported that the rate of ethylene production is correlated positively with the rate of chlorophyll degradation (Aharoni et al., 1985; Makhlouf et al., 1989b; Wang, 1979). However, in our study with the high $\mathrm{CO}_{2}$ atmosphere at $10 \mathrm{C}$, ethylene production had increased but the green color was retained. High $\mathrm{CO}_{2}$ probably caused a stress condition which induced ethylene production but did not have a deteriorative effect on color (Aharoni et al., 1985). However, with extended storage, ethylene can cause degradation of chlorophyll (Makhlouf et al., 1989b). We found that high $\mathrm{CO}_{2}$ and low $\mathrm{O}_{2}$ retained the green color of florets to about the same degree at $10 \mathrm{C}$. However, others have indicated that elevated $\mathrm{CO}_{2}$ was more effective than reduced $\mathrm{O}_{2}$ in retarding the yellowing of broccoli (Kasmire et al., 1974; Lebermann et al., 1968; Makhlouf et al., 1989a). The differences in the results maybe due to the differences
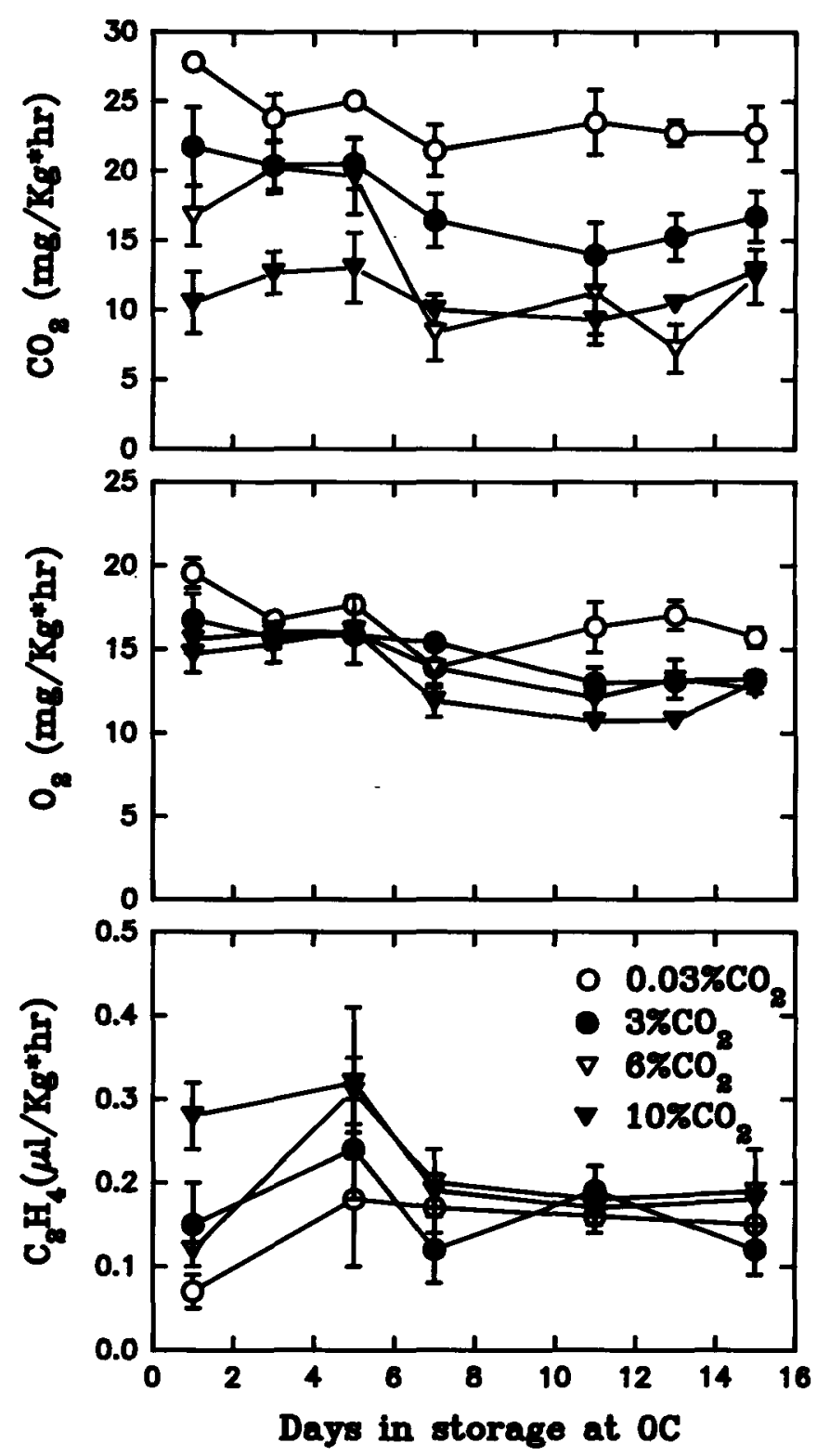

Fig. 3. Rates of $\mathrm{CO}_{2}$ production, $\mathrm{O}_{2}$ consumption, and ethylene production of broccoli florets during storage at $0 \mathrm{C}$ under air or high $\mathrm{CO}_{2}$ atmospheres. Vertical lines represent SE. SE bars not shown when within symbols.

in the temperature and length of storage periods.

High $\mathrm{CO}$, was more effective than low $\mathrm{O}_{2}$ in reducing the incidence of soft rot at $10 \mathrm{C}$, and of undesirable odor at all temperatures. However, this comparison may not be valid because the incidence of soft rot of samples held in air (control) was lower in the $\mathrm{CO}_{2}$ experiment (Table 2) than in the $\mathrm{O}_{2}$ experiment (Table 1), possibly due to the differences in maturity of broccoli and the degree of field and packing house contamination.

A $0.5 \% \mathrm{O}_{2}$ level at 0 and $5 \mathrm{C}$ and $1 \% \mathrm{O}_{2}$ level at $10 \mathrm{C}$ is recommended for broccoli florets to prevent the development of offodor induced by low $\mathrm{O}_{2}$. Others have reported that off-odor occurred with raw broccoli heads held in $\mathrm{O}_{2}$ below $1 \%$ at $2.5 \mathrm{C}$ (Kasmire et al., 1974) and by cooked broccoli heads that were held in $\mathrm{O}_{2}$ below $0.25 \%$ at 5 and 7.5C (Lipton and Hams, 1974).

Our results indicate that $0.5 \% \mathrm{O}_{2}$ and $10 \% \mathrm{CO}_{2}$ at 0 and $5 \mathrm{C}$, and $1 \% \mathrm{O}_{2}$ and $10 \% \mathrm{CO}_{2}$ at $10 \mathrm{C}$ seemed to be the best atmosphere for preservation of broccoli florets without risking the development of undesirable odors and disorders. These $\mathrm{O}_{2}$ levels were lower than 

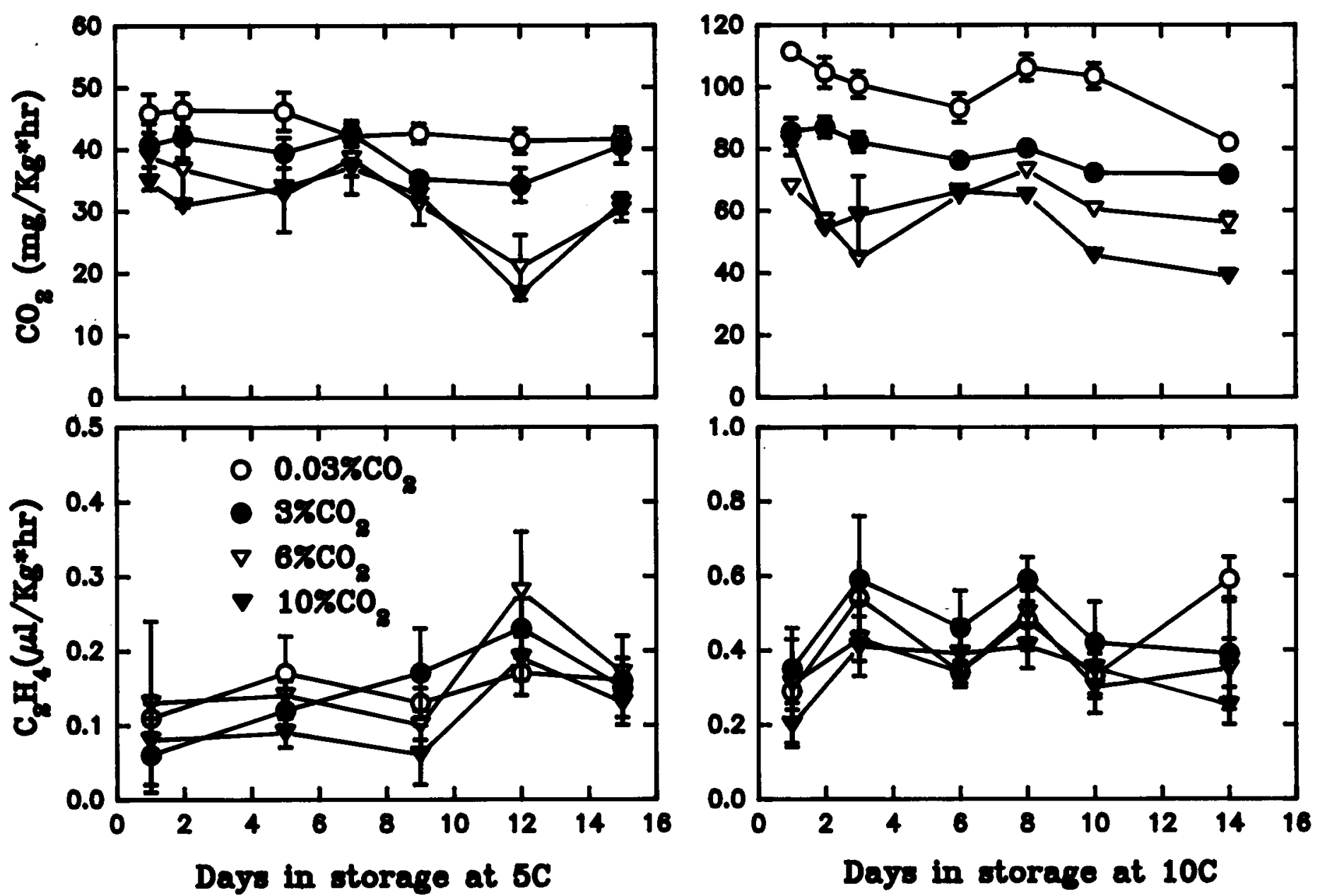

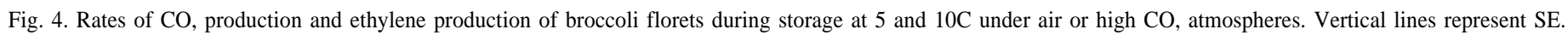
SE bars not shown when within symbols.

Table 2. Incidence of soft rot and browning and development of objectionable odor during storage of broccoli florets at 0,5 , and 10C under air or high $\mathrm{CO}_{2}$ atmospheres

\begin{tabular}{lccccc}
\hline \hline \multirow{2}{*}{$\begin{array}{l}\text { Storage } \\
\left({ }^{\circ} \mathrm{C}\right)\end{array}$} & & & & \multicolumn{2}{c}{ Odor $^{y}$} \\
\cline { 5 - 6 } & Treatment & Soft rot $^{2}$ & Browning & Raw & Cooked \\
\hline 0 & $0.03 \% \mathrm{CO}_{2}$ & $0 \mathrm{a}$ & $0 \mathrm{a}$ & $2.0 \mathrm{a}$ & $0.7 \mathrm{a}$ \\
& $3 \% \mathrm{CO}_{2}$ & $0 \mathrm{a}$ & $0 \mathrm{a}$ & $1.0 \mathrm{~b}$ & $0 \mathrm{a}$ \\
& $6 \% \mathrm{CO}_{2}$ & $0 \mathrm{a}$ & $0 \mathrm{a}$ & $1.0 \mathrm{~b}$ & $0 \mathrm{a}$ \\
5 & $10 \% \mathrm{CO}_{2}$ & $0 \mathrm{a}$ & $0 \mathrm{a}$ & $1.0 \mathrm{~b}$ & $0.7 \mathrm{a}$ \\
& $0.03 \% \mathrm{CO}_{2}$ & $0 \mathrm{a}$ & $0 \mathrm{a}$ & $1.7 \mathrm{a}$ & $0.3 \mathrm{a}$ \\
& $3 \% \mathrm{C} \mathrm{O}_{2}$ & $0 \mathrm{a}$ & $0 \mathrm{a}$ & $1.0 \mathrm{a}$ & $0.7 \mathrm{a}$ \\
& $6 \% \mathrm{CO}_{2}$ & $0 \mathrm{a}$ & $0 \mathrm{a}$ & $1.0 \mathrm{a}$ & $0.7 \mathrm{a}$ \\
10 & $10 \% \mathrm{CO}_{2}$ & $2 \mathrm{a}$ & $2 \mathrm{a}$ & $1.0 \mathrm{a}$ & $0.3 \mathrm{a}$ \\
& $0.03 \% \mathrm{CO}_{2}$ & $17 \mathrm{a}$ & $6 \mathrm{a}$ & $1.0 \mathrm{a}$ & $0 \mathrm{a}$ \\
& $3 \% \mathrm{CO}_{2}$ & $4 \mathrm{~b}$ & $0 \mathrm{a}$ & $1.3 \mathrm{a}$ & $0 \mathrm{a}$ \\
& $6 \% \mathrm{CO}_{2}$ & $2 \mathrm{~b}$ & $0 \mathrm{a}$ & $1.3 \mathrm{a}$ & $0 \mathrm{a}$ \\
& $10 \% \mathrm{CO}_{2}$ & $2 \mathrm{~b}$ & $0 \mathrm{a}$ & $1.7 \mathrm{a}$ & $0 \mathrm{a}$
\end{tabular}

${ }^{\bar{x}}$ Number of injured florets $\times 100$ number of observed florets.

${ }^{y}$ Rated on a scale of 0 to 4 , with $0=$ normal and $4=$ severely objectionable. ${ }^{x}$ Mean separation within each temperature by Duncan's multiple range test, $P=0.05$.

those recommended for broccoli heads at 0 to 5C (Saltveit, 1993), suggesting that a smaller gradient of $\mathrm{O}_{2}$ concentration from the external to internal tissue had occurred in florets than in heads due to the less distance of gas diffusion in florets. When florets were held at $10 \mathrm{C}$, it is important to keep $\mathrm{O}_{2}$ levels above $1 \%$. The results could be beneficial for storage of packaged broccoli florets, because ambient $\mathrm{O}_{2}$ of packaged florets can become very low due to the high respiration rate of florets as compared with heads (Bastrash et al., 1993; Rushing, 1990).

\section{Literature Cited}

Aharoni, N., S. Philosoph-Hadas, and R. Barkai-Golan. 1985. Modified atmospheres to delay senescence and decay of broccoli. Proc. 4th Natl. Controlled Atmosphere Conf. p. 169-177. Dept. of Hort. Sci., Raleigh, N.C.

Anelli, G., F. Mencarelli, and F. Guaraldi. 1984. Short storage of Brassica oleracea L. and Brassica campestris L. in different types of modified atmospheres. Acta Hort. 157: 177-184.

Ballantine, A., R. Stark, and J.D. Selman. 1988. Modified atmosphere packaging of broccoli florets. Intl. J. Food Sci. Technol. 23:353-360.

Barth, M. M., E.L. Kerbel, S. Broussard and S.J. Schmidt. 1993. Modified atmosphere packaging protects market quality in broccoli spears under ambient temperature storage. J. Food Sci. 58:1070-1 072.

Bastrash, S., J. Makhlouf, F. Castaigne, and C. Willemot. 1993. Optimal controlled atmosphere conditions for storage of broccoli florets. J. Food Sci. 58:338-341, :360.

Berrang, M. E., R.E. Brackett, and L.R. Beuchat. 1990. Microbial, color and textural qualities of fresh asparagus, broccoli, and cauliflower stored under controlled atmosphere. J. Food Prot. 53:391-395.

Brecht, P.E. 1980. Use of controlled atmospheres to retard deterioration of produce. Food Technol. 34(3):45-50.

Kader, A.A. 1986. Biochemical and physiological basis for effects of controlled and modified atmospheres on fruits and vegetables. Food Technol. 40(5):99-104.

Kasmire, R. F., A.A. Kader, and J.A. Klaustermeyer. 1974. Influence of aeration rate and atmospheric composition during simulated transit on 
visual quality and off-odor production by broccoli. HortScience 9:228229.

Lebermann, K.W., A.I. Nelson, and M.P. Steinberg. 1968. Post-harvest changes of broccoli stored in modified atmospheres. 1. Respiration of shoots and color of flower heads. Food Technol. 22:487-490.

Lipton, W.J. and C.M. Harris. 1974. Controlled atmosphere effects on the market quality of stored broccoli (Brassica oleracea L., Italica Group). J. Amer. Soc. Hort. Sci. 99:200-205.

Makhlouf, J., F. Castaigne, J. Arul, C. Willemot, and A. Gosselin. 1989a. Long-term storage of broccoli under controlled atmosphere. HortScience 24:637-639.
Makhlouf, J., C. Willemot, J. Arul, F. Castaigne, and J. Emend. 1989b. Regulation of ethylene biosynthesis in broccoli flower buds in controlled atmospheres. J. Amer. Soc. Hort. Sci. 114:955-958.

Rushing, J.W. 1990. Cytokinins affect respiration, ethylene production, and chlorophyll retention of packaged broccoli florets. HortScience 25:88-90.

Saltveit, M.E., Jr. 1993. A summary of CA and MA requirements and recommendations for the storage of harvested vegetables. Proc. 6th Natl. Conf. p. 800-818. Cornell Univ., Ithaca, N.Y.

Wang, C.Y. 1979. Effect of short-term high $\mathrm{CO}_{2}$ treatment on the market quality of stored broccoli. J. Food Sci. 44: 1478-1482. 